\title{
EKSPERIMEN PESAWAT ATWOOD BERBASIS PENGOLAHAN APLIKASI TRACKER UNTUK MENGAMATI FENOMENA GERAK LURUS BERATURAN DAN GERAK LURUS BERUBAH BERATURAN PADA PEMBELAJARAN FISIKA SMA
}

\author{
Firman Nugraha ${ }^{1, a)}$, Resti Wulansari ${ }^{1)}$, Inka Danika ${ }^{1)}$, Vina Nurafiah ${ }^{1)}$, \\ Asri Nur Lathifah ${ }^{1)}$, Fitri Nurul Sholihat ${ }^{1)}$, Hana Susanti ${ }^{1)}$, \\ Muhamad Gina Nugraha ${ }^{1, b}$, Kartika Hajar Kirana ${ }^{2)}$ \\ ${ }^{1}$ Departemen Pendidikan Fisika FPMIPA UPI, Jl. Dr. Setiabudhi No.229, Bandung 40154. \\ ${ }^{2}$ Departemen Geofisika FMIPA UNPAD, Jl. Raya Bandung-Sumedang Km 21, Jatinangor 45363.

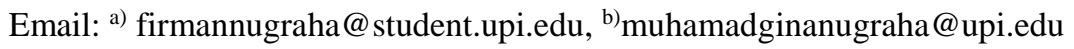

\begin{abstract}
Abstrak
Fisika merupakan salah satu cabang IPA yang mendasari perkembangan teknologi, sehingga proses pembelajaran Fisika seyogyanya tidak hanya menekankan pada penguasaan konsep tetapi juga pada aspek penemuan. Oleh karena itu, kegiatan eksperimen dipandang sangat penting dalam pembelajaran Fisika. Salah satu eksperimen yang umum dilakukan ialah eksperimen Gerak Lurus Beraturan (GLB) dan Gerak Lurus Berubah Beraturan (GLBB) dengan menggunakan alat Pesawat Atwood. Hasil observasi menunjukkan bahwa pengukuran parameter gerak pada pesawat atwood dilakukan secara manual, yaitu menggunakan mistar dan stopwatch untuk menentukan kecepatan dan percepatan gerak benda, sehingga data yang diperoleh bersifat subjektif dan kurang menunjukkan karakteristik GLB dan GLBB. Salah satu solusi ialah menggunakan aplikasi Tracker. Pada eksperimen ini gerakan benda direkam menggunakan kamera High definition-HD dengan kecepatan mengambil gambar 24 frame per second. Hasil pengolahan Tracker untuk GLB memberikan grafik posisi fungsi waktu $(y=f(t))$ berbentuk garis lurus miring kanan dan grafik kecepatan fungsi waktu $(v=f(t))$ berbentuk garis lurus mendatar. Sedangkan untuk GLBB, pengolahan tracker memberikan grafik posisi fungsi waktu $(y=f(t))$ berbentuk kuadratik dan grafik kecepatan fungsi waktu $(v=f(t))$ berbentuk garis lurus miring kanan. Berdasarkan hasil analisis, dapat disimpulkan bahwa pemanfaatan aplikasi tracker pada pesawat atwood mampu menunjukkan karakteristik gerak GLB dan GLBB sehingga layak digunakan dalam pembelajaran fisika di sekolah.
\end{abstract}

Kata-kata kunci: GLBB, GLB, Tracker, Pesawat Atwood.

\begin{abstract}
Physics is one of science branch that become the cornerstone of many of advanced technology development, so the process of learning physics should not only focused on the concept mastery but also concerning the discovery aspect. In that case, experiment activity has been really important in learning physics. One of the most common experiment activity which used to explain uniform rectinilier motion and accelerated uniform rectinlier motion is using Atwood Machine. From the observations, it is showed that the measure of the motion parameter has done manually using stopwatch and ruler. The result from this experiment was subjective and also it was cannot give exact characteristic of this two motion. One of the solution for this problem is use tracker application. In this experiment, a body is recorded using High Definition camera with 24 frame per second shutter speed. The result from data processing with tracker has shown that the graphic of position depend on time for uniform rectilinier motion $(y=f(t))$ is a linier line with positive gradient and the graphic of the velocity depend on time $(v=f(t))$ is flat line shaped. For the uniform accelerated rectilinier motion, the graphic of position depend on time $(\mathrm{y}=\mathrm{f}(\mathrm{t}))$ is a graphic from quadratic function and the graphic of the velocity depend on time $(v=f(t))$ is a linier line with positive gradient. Based on the result of the data analysis, it is concluded that the use of tracker application on atwood
\end{abstract}


machine is able to show the characteristic of uniform rectilinier motion and uniform accelerated rectilinier motion so it is worth to use in physics learning at school.

Keywords: Uniform Accelerated Rectilinier Motion, Uniform Rectilinier Motion, Tracker, Atwood Machine.

\section{PENDAHULUAN}

Fisika bukan hanya sekedar pelajaran teori yang manfaatnya tidak dapat dirasakan masyarakat. Fisika merupakan salah satu ilmu alam yang menjadi dasar berbagai macam teknologi di dunia. Pembelajaran eksperimen sudah seharusnya tidak hanya berpusat pada penguasaan konsep tetapi juga harus memperhatikan aspek penemuan. Memandang situasi ini, pembelajaran dengan metode eksperimen menjadi sangat penting untuk dilakukan karena eksperimen merupakan penyajian materi yang melibatkan siswa secara aktif sehingga siswa tersebut dapat mengalami dan membuktikan sendiri apa yang sedang ia pelajari [1]. Dengan mempelajari sendiri apa yang sedang dipelajari siswa tidak hanya mampu menguasai konsep tetapi juga dapat mengembangkan kemampuan lain dan keterampilan tentang bagaimana membangun konsepnya sendiri.

Penggunaan media dalam pembelajaran sangat berpengaruh pada keefektifan pembelajaran [2], oleh sebab itu pemilihan dan penggunaan alat dan metode dalam eksperimen perlu dikaji dan dikembangkan supaya menghasilkan data yang tepat dan akurat. Salah satu percobaan yang umum dilakukan di sekolah ialah percobaan untuk membuktikan karakteristik gerak lurus berubah beraturan (GLBB) dan karakteristikk gerak lurus beraturan (GLB) dengan menggunakan set alat pesawat atwood seperti ditunjukkan pada gambar 1 . Dalam pelaksanaannya, umumnya pengukuran parameter gerak benda pada pesawat atwood masih dilakukan secara manual. Mistar panjang atau meteran digunakan untuk mengukur jarak tempuh benda dan waktu tempuh benda diukur menggunakan stopwatch. Kedua proses pengukuran ini dipandang sangat rentan kesalahan karena faktor alat ukur yang kurang presisi maupun kesalahan pada saat pengambilan data oleh siswa, sehingga data hasil pengukuran sangat subjektif.

Salah satu solusi yang diprediksi dapat menghasilkan data parameter gerak yang lebih akurat ialah menggunakan perangkat lunak Tracker. Tracker merupakan perangkat lunak/software untuk menganalisis gerak benda melalui video, sehingga dapat dihasilkan parameter perubahan posisi, paramater kecepatan, percepatan, energi kinetik, energi potensial dan parameter lainnya yang dimiliki objek yang bergerak [3]. Penggunaan perangkat lunak ini bukanlah metode yang asing untuk menganalisis gerak. Kemampuan rekam jejak dari perangkat lunak ini pernah digunakan untuk menentukan nilai koefisien viskositas [4], menganalisis percepatan gravitasi $[5,6,7]$ dan menganalisis gerak daun akibat gerhana matahari sebagian [8].

Dengan menggunakan perangkat lunak tracker, pengukuran parameter gerak benda dapat dilakukan dengan lebih teliti dan lebih akurat, sehingga siswa dapat menemukan karakteristik gerak GLBB dan GLB dengan benar.

\section{METODE PENELITIAN}

Pada penelitian ini digunakan set alat percobaan pesawat atwood dengan skema alat seperti ditunjukkan gambar 1 .
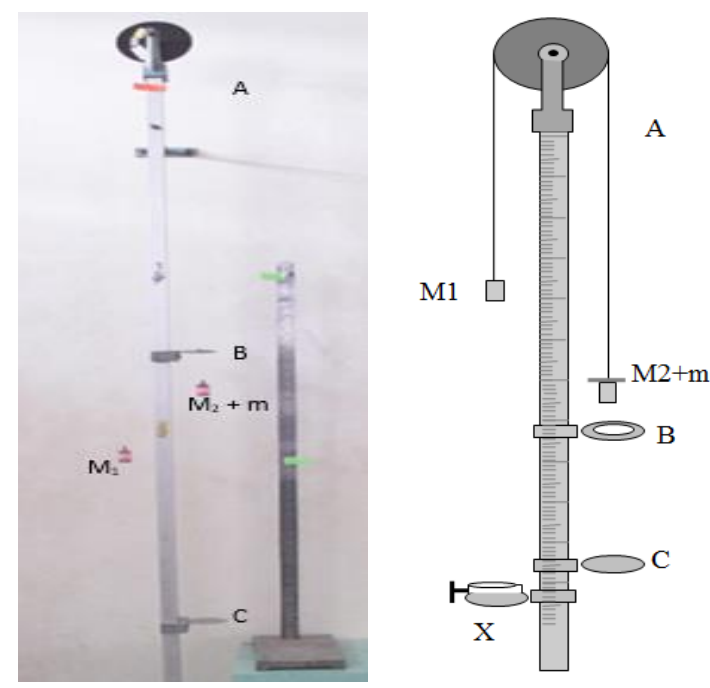

Gambar 1. Setting alat percobaan pesawat atwood 
Pada kondisi awal beban M1 yang massanya sama dengan M2 ditahan di posisi X menggunakan baut pengunci. Kemudian beban M1 dilepaskan sehingga beban bergerak naik dan beban M2 yang telah diberi beban tambahan $m$ berbentuk keping bergerak turun bersamaan dari posisi A ke posisi B. Pada segmen AB, gerak benda yang terjadi adalah Gerak Lurus Berubah Beraturan (GLBB) dikarenakan beban M2+m lebih besar dari M1. Sedangkan pada segmen BC, beban tambahan $m$ telah lepas dari M2, sehingga gerak benda yang terjadi adalah gerak Lurus Beraturan (GLB) dikarenakan beban M1 dan M2 memiliki massa yang sama sehingga tidak ada resultan gaya pada sistem tersebut.

Pada eksperimen ini digunakan tali penghubung dengan jenis tali pancing dengan massa tali $=0,24$ gram. Beban yang digunakan memiliki massa yang sama (identik) sebesar $\mathrm{M} 1=\mathrm{M} 2=72,26$ gram dan dipasang di kedua ujung tali pancing. Selain itu, pada beban juga ditempelkan warna mencolok sebagai titik massa untuk memudahkan menganalisis dalam menggunakan aplikasi tracker.

Tracker merupakan Perangkat lunak untuk menganalisis video yang dikembangkan oleh Open Source Physics (OSP) dengan kerangka Java [3]. Perangkat lunak ini melacak gerak benda dengan mengidentifikasi beberapa pixel dari luasan yang ditentukan dan menganalisis posisinya pada setiap frame. Untuk menghasilkan data yang akurat diperlukan rekaman video yang jelas. Pada penelitian ini, gerakan beban pada pesawat Atwood direkam menggunakan kamera yang memiliki resolusi tinggi (high definition) dengan kecepatan pengambilan gambar 24 frame per second (fps). Video dianalis menggunakan aplikasi Tracker sehingga dihasilkan grafik perubahan posisi setiap waktu $(\mathrm{y}=\mathrm{f}(\mathrm{t}))$ dan grafik perubahan kecepatan setiap waktu $(\mathrm{v}=\mathrm{f}(\mathrm{t}))$ untuk gerakan benda pada segmen A-B dan B-C. Dari kedua grafik ini akan diperoleh karakteristik gerak GLBB dan GLB.

\section{HASIL DAN PEMBAHASAN}

Berdasarkan hasil percobaan diperoleh rekaman jejak gerak benda dengan menggunakan perangkat lunak tracker seperti ditunjukkan gambar 2. Rekaman video dianalisis sehingga diperoleh grafik perubahan posisi setiap waktu $(\mathrm{y}=\mathrm{f}(\mathrm{t}))$ untuk kedua segmen gerak yang diamati yaitu segmen A-B dan B-C seperti terlihat pada gambar 3. Selain itu diperoleh juga grafik perubahan kecepatan setiap waktu $(\mathrm{v}=\mathrm{f}(\mathrm{t}))$ untuk kedua segmen gerak seperti terlihat pada gambar 4 .

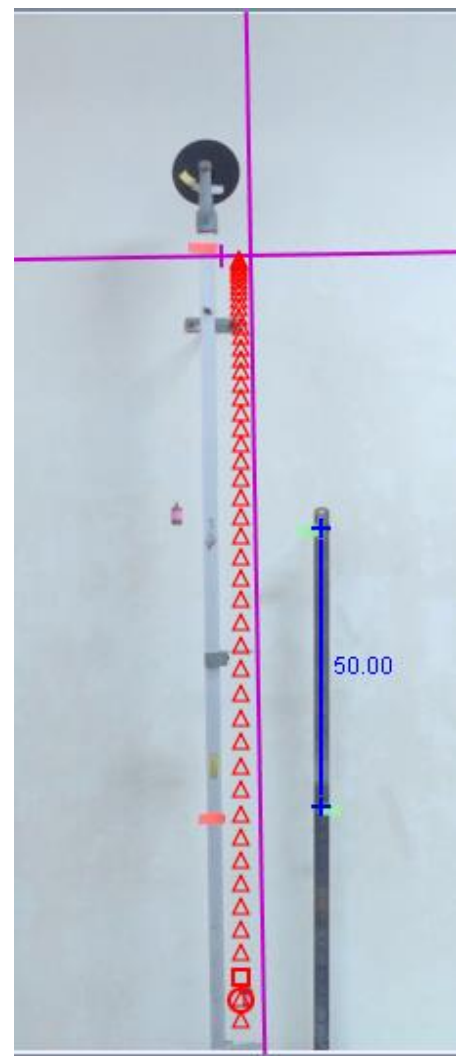

Gambar 2. hasil perekaman jejak gerak beban pada perangkat lunak tracker 


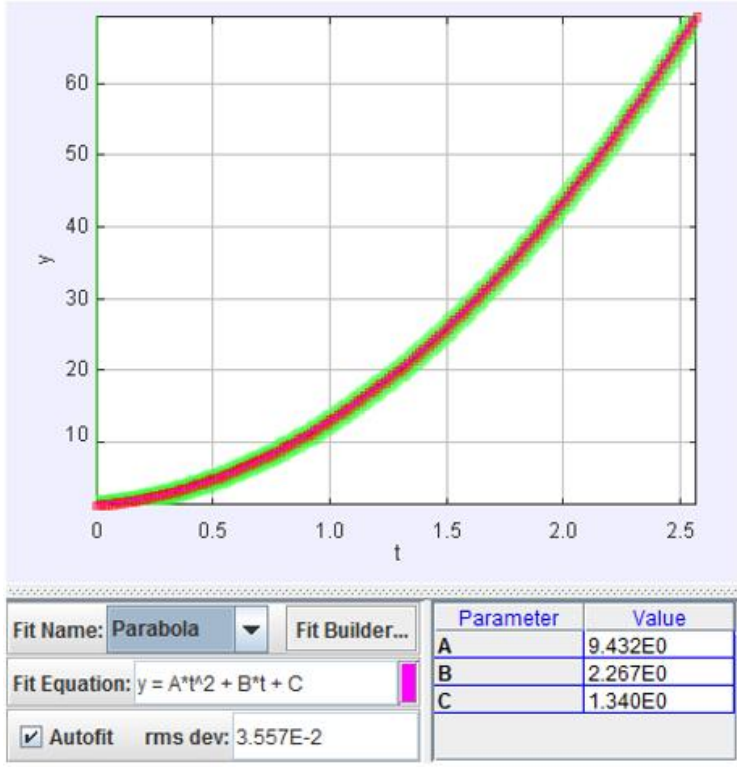

(a)

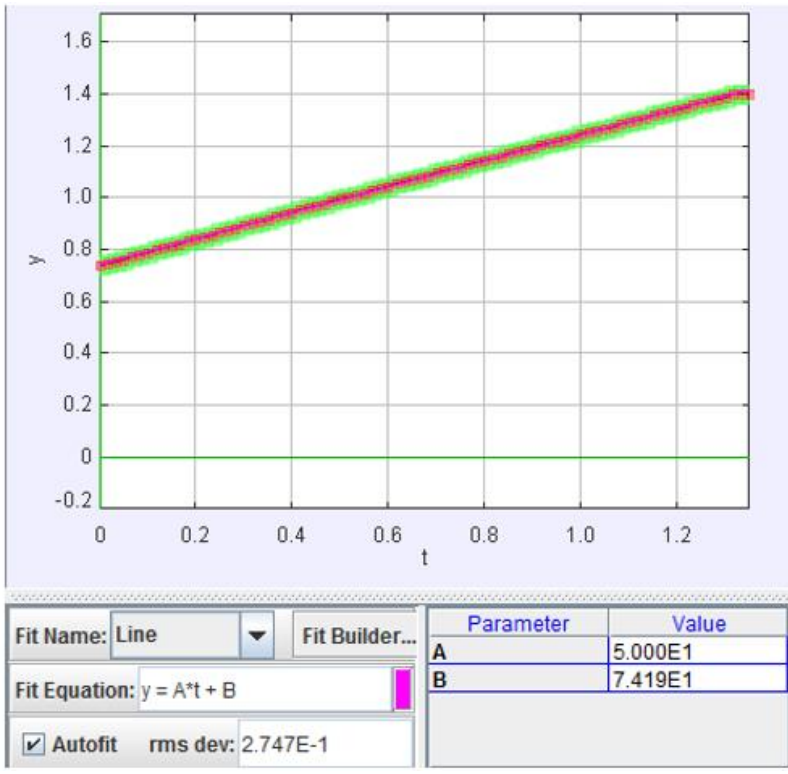

(b)

Gambar 3. Grafik perubahan posisi benda setiap waktu; a) pergerakan benda pada lintasan A-B; b) pergerakan benda pada lintasan B-C

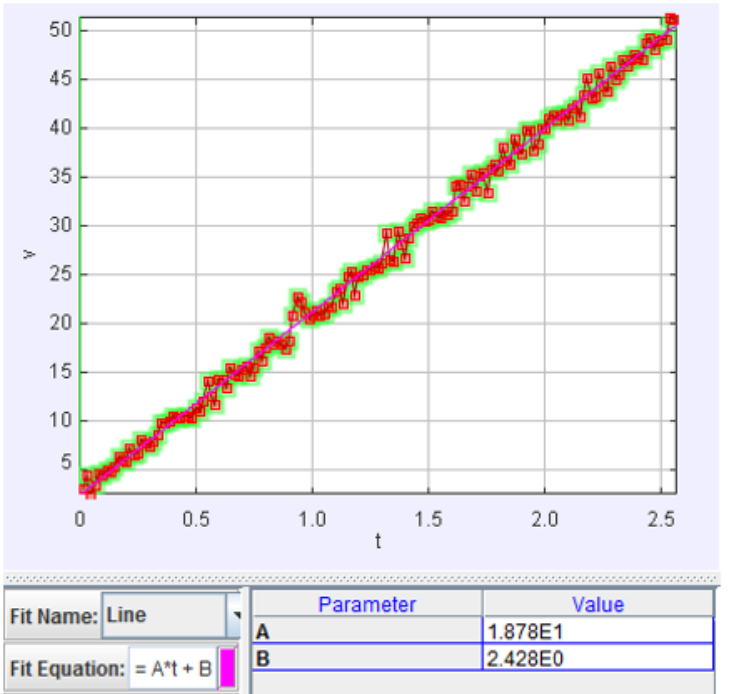

(a)

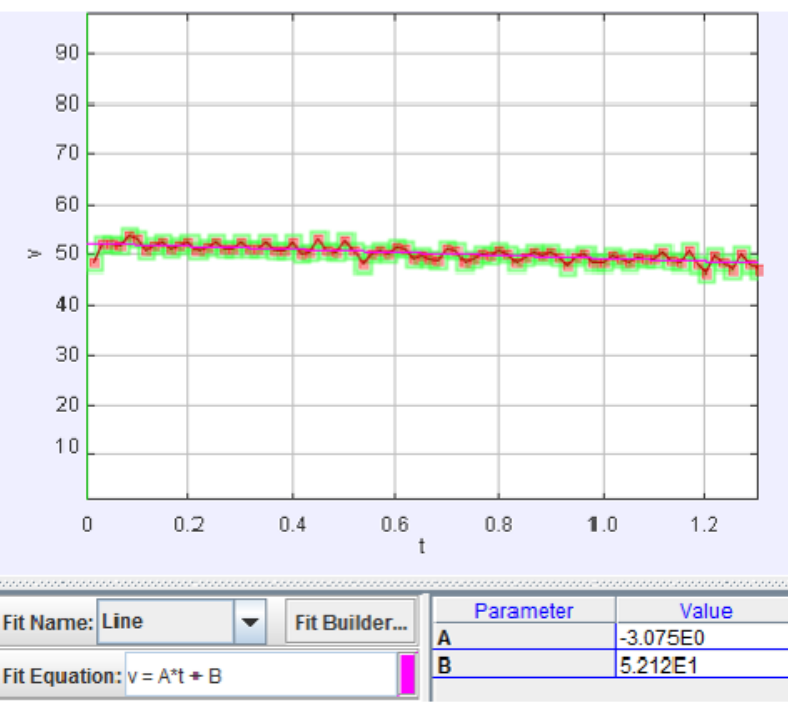

(b)

Gambar 4. Grafik perubahan kecepatan benda setiap waktu; a) pergerakan benda pada lintasan A-B; b) pergerakan benda pada lintasan B-C

Gambar 2, 3a, dan 4a menunjukkan bahwa pada lintasan gerak A-B, beban mengalami percepatan gerak. Hal ini terlihat dari perubahan posisi yang semakin membesar dalam waktu yang sama dan juga dipertegas pada gambar 4 bahwa kecepatan gerak benda berubah terhadap waktu. Hal ini cukup mudah dipahami karena pada segmen gerak A-B, beban M2 yang direkam mendapat tambahan beban sebesar m, sehingga terdapat resultan gaya pada sistem yang searah dengan pergerakan beban M2. Dari hasil ini pun diperoleh nilai percepatan gerak benda yaitu dilihat dari persamaan gerak kuadratik pada gambar $3 a$ ataupun kemiringan grafik pada gambar 4a. Hasil analisis ini menunjukkan bahwa penggunaan Tracker dapat menunjukkan karateristik GLBB dengan sangat baik jika dibandingkan dengan pengukuran menggunakan stopwatch dan mistar. 
Pada segmen gerak B-C, beban tambahan sudah tersangkut dititik B sehingga pada sistem hanya ada baban M1 dan M2 yang massanya sama. Pada segmen gerak B-C, terlihat bahwa perubahan posisi terhadap waktu memiliki pola yang linier seperti ditunjukkan gambar $3 \mathrm{~b}$, hal ini memberikan informasi bahwa gerakan beban pada segmen B-C bergerak dengan kecepatan yang relatif konstan jika dibandingkan dengan segmen A-B. Perubahan kecepatan yang terjadi pada segmen B-C seperti ditunjukkan gambar 4b diprediksi karena gesekan pada katrol yang memang tidak dapat diabaikan. Namun, meskipun demikian, perubahan kecepatan pada segmen B-C cukup kecil yaitu sebesar 7,776\%/detik dari kelajuan awalnya. Berdasarkan hasil analisis gerak pada segmen B-C dapat dikatakan bahwa penggunaan tracker masih sangat layak digunakan untuk menunjukkan karakteristik GLB.

Berdasarkan hasil pengolahan dan analisis data dapat dikatakan bahwa set alat Pesawat Atwood yang digunakan dapat menjadi media untuk menyampaikan fenomena GLBB dan GLB kepada siswa. Beberapa penelitian yang melibatkan pengukuran gerak juga menunjukkan bahwa penggunaan tracker menunjukkan hasil yang lebih akurat.[4,5].

\section{SIMPULAN}

Berdasarkan hasil penelitian dapat disimpulkan bahwa penggunaan tracker pada percobaan pesawat atwood dapat menunjukkan karakteristik gerak lurus berubah beraturan (GLBB) dan gerak lurus beraturan (GLB) dengan sangat baik. Pemanfaatan tracker pada kegiatan eksperimen/percobaan dapat memberikan data lebih presisi dan lebih logis untuk siswa analisis.

\section{UCAPAN TERIMAKASIH}

Penulis mengucapkan terimakasih kepada seluruh pihak yang telah membantu menyelesaikan penelitian ini.

\section{REFERENSI.}

[1] Nugraha, M G dan K H Kirana, "Profil Keterampilan Berpikir Kritis Mahasiswa Fisika Dalam Perkuliahan Eksperimen Fisika Berbasis Problem Solving,” dalam Seminar Nasional Fisika (SNF) vol.5, p-ISSN: 2339-0654, e-ISSN: 2476-9398, Jakarta, Oktober 2015, pp.201-204.

[2] Anderson, J.L. \& Barnett, M. Learning Physics with Digital Game Simulations in Middle School Science. Journal of Science Educucation and Technololgy 22(6) : 914. doi:10.1007/s10956-013-94388

[3] Douglas Brown dan Wolfgang Christian, "Tracker". 2012 di unduh dari http://www.opensourcephysics.org

[4] Marliani, Fitri, dkk, "Penerapan Analisis Video Tracker dalam Pembelajaran Fisika SMA Untuk Menentukan Nilai Koefisien Viskositas Fluida". Prosiding Simposium Nasional Inovasi dan Pembelajaran Sains 2015, p. 333-336.

[5] Afifah, Nur, dkk, "Metode Sederhana Menentukan Percepatan Gravitasi Bumi Menggunakan Aplikasi Tracker Pada Gerak Parabola Sebagai Media dalam Pembelajaran Fisika SMA”. Prosiding Simposium Nasional Inovasi dan Pembelajaran Sains 2015, p. 305-308.

[6] Sholihat, F N, dkk, "Anomali Medan Gravitasi Permukaan (g) Akibat Gerhana Matahari Sebagian (GMS) 9 Maret 2016 Menggunakan Analisis Tracker pada Kater's Reversible Pendulum”, dalam Seminar Nasional Fisika (SNF) Vol.5, p-ISSN: 2339-0654e-ISSN: 2476-9398, Jakarta, Oktober 2016.

[7] Setyadin, A H dkk, "Optimalisasi Bandul Matematis Menggunakan Tracker Dalam Penentuan Perubahan Percepatan Gravitasi Permukaan Bumi (g) Akibat Gerhana Matahari Sebagian (GMS) 9 Maret 2016", dalam Seminar Nasional Fisika (SNF) Vol.5, p-ISSN: 2339-0654e-ISSN: 2476-9398, Jakarta, Oktober 2016.

[8] Alyasyfi, M N, dkk, "Pengaruh Perubahan Intensitas Cahaya Akibat Gerhana Matahari Sebagian Terhadap Gerak Daun Bauhinia Purpurea", dalam Seminar Nasional Fisika (SNF) Vol.5, p-ISSN: 2339-0654e-ISSN: 
